\title{
Cloning, sequencing and characterisation of a Listeria monocytogenes gene encoding a fibronectin-binding protein
}

\author{
PHILIPPE GILOT, YVES JOSSIN and JEAN CONTENT \\ Department of Virology, Pasteur Institute, Brussels, Belgium
}

\begin{abstract}
Listeria monocytogenes is a gram-positive, non-sporulating food-borne pathogen of man and animals that is able to invade many eukaryotic cells. L. monocytogenes possesses several proteins that bind fibronectin. In this study, an $L$. monocytogenes DNA library in pUC19 was screened with fibronectin and a gene encoding a 24.6-kDa fibronectinbinding protein (Fbp) was isolated and sequenced. Transcripts of the $f b p$ gene were found in wild-type, in $\Delta p r f A$, and PrfA-S183A strains, despite the presence of a 'PrfAlike' box around its ribosome-binding site. The $f b p$ gene was found to be present in all tested isolates of the species $L$. monocytogenes and a homologous DNA fragment was amplified in $L$. welshimeri. No homologies between the $f b p$ gene and its translation product with any other DNA or proteins deposited in databanks were found. Restriction endonuclease-PCR (RE-PCR) showed that the $f b p$ gene displays a degree of allelic variation among isolates of $L$. monocytogenes, whereas the corresponding amplified fragment of $L$. welshimeri seems to be monomorphic among isolates of this species. REPCR with Hha I, Dde I or Taq I produced DNA banding profiles specific for each of these two species, allowing their identification.
\end{abstract}

\section{Introduction}

Listeria monocytogenes is a gram-positive, non-sporulating, food-borne pathogen of man and animals. This facultative intracellular organism is widely distributed in the environment and is responsible for severe human infections. Human disease due to L. monocytogenes usually occurs in pregnant women, the newborn, the elderly and immunocompromised patients. Clinical manifestations range from mild flu-like symptoms and gastro-enteritis to septicaemia, central nervous system infections and feto-maternal infections with abortion, premature labour or birth of an infected child. Despite the low incidence of listeriosis, the disease is associated with a high mortality rate $(20-40 \%)[1,2]$. While all other species of the genus Listeria ( $L$. innocua, L. welshimeri, L. seeligeri, L. ivanovii, $L$. murrayi) are also widely distributed in the environment, only L. monocytogenes is considered pathogenic to man. Nevertheless, occasional human infections caused

Received 10 Dec 1999; revised version received 10 March 2000; accepted 20 March 2000.

Corresponding author: Dr P. Gilot (e-mail: pgilot@ben. vub.ac.be). Present address: Laboratoire de Pathologie Infectieuse et Immunologie, INRH Nouzilly, France. by $L$. ivanovii and $L$. seeligeri have been reported $[3,4]$.

In recent years a number of outbreaks and sporadic cases of listeriosis have been linked to L. monocytogenes, emphasising the continued threat to public health posed by listerial contamination of foods $[1,2,5]$. Elimination of this pathogen from foods is very difficult because of its ubiquitous distribution and its ability to grow at refrigeration temperature. Thus, the complete understanding of the molecular mechanism governing the infectious process of L. monocytogenes, as well as active surveillance of foodstuffs and food-processing equipment, are particularly important in the control of listeriosis.

Adhesion of L. monocytogenes to host tissues is an essential event for invasion leading to infection. In recent years, several listerial components (InlA, InlB, p60, p104, ActA, $\alpha$-D-galactose, lipoteichoic acid, $N$-acetylneuraminic acid) were shown to interact with eukaryotic cells and tissues indicating that, as in other bacterial pathogens, adherence is a very complex and multifactorial mechanism [6-13]. An earlier study reported that L. monocytogenes binds to human fibronectin, a 450$\mathrm{kDa}$ dimeric glycoprotein found in body fluids, on the surface of eukaryotic cells and in an insoluble component 
of the extracellular matrix. The binding of fibronectin to L. monocytogenes appeared to be saturable and dependent on proteinaceous receptors. Several of these fibronectin-binding proteins were identified in cell lysates and cell-wall extracts of the bacterium [14].

In this study, an L. monocytogenes gene encoding a 24.6-kDa protein that binds human fibronectin has been cloned, sequenced and characterised.

\section{Materials and methods}

\section{Bacterial strains, plasmid and growth conditions}

L. monocytogenes strain 90/636 was used in all experiments. This strain, serovar $1 / 2 \mathrm{a}$-esterase type IB, was isolated in Belgium from a 57-year-old man suffering from meningo-encephalitis. The LD50 values of the strain for conventional and carrageenan-treated $\mathrm{NMRI} / \mathrm{Han}$ white mice were $9.2 \times 10^{2} \mathrm{cfu}$ and $<11 \mathrm{cfu}$, respectively [15]. The following L. monocytogenes strains were also used in some experiments: 62-3-90 (sv 1/2a-esterase type IC, cheese isolate), 92-066-01 (sv 1/2a-esterase type ID, cheese isolate) 90-266 (sv 1/2a-esterase type IE, clinical isolate), 90-110 (sv 1/2a-esterase type IF, clinical isolate), 92-782 (sv 1/2a-esterase type IG, clinical isolate), 92-598 (sv 1/2a-esterase type IH, clinical isolate), 91-089 (sv 1/2a-esterase type Ii, clinical isolate), 90-326 (sv 1/2a-esterase type IJ, clinical isolate), 265-62-90 (sv 3a-esterase type IIA, cheese isolate), 91-371 (sv 1/2a-esterase type IIG, clinical isolate), 91-008 (sv 4b-esterase type IIH, clinical isolate), ATCC 51772, ATCC 51776, ATCC 51777, ATCC 51778, ATCC 51779, ATCC 51780, ATCC 51781, ATCC 51782, LO28 [16], BUG 802 [17] and BUG 1236 [18]. Apart from the last three strains, which were obtained from the Unité des Interactions Bactéries-Cellules (Pasteur Institute, Paris, France), strains were from the collection of the Belgian Reference Centre for listeriosis, Institute of Hygiene and Epidemiology (IHE), Brussels, Belgium. Other Listeria spp. used were L. innocua serovar 6a, $L$. innocua serovar 6b, L. innocua 95-013, 15 strains of L. welshimeri, L. ivanovii, L. seeligeri 024-20, $L$. seeligeri 1140-09-03, L. seeligeri 89-59-06 (all from IHE) and L. grayi CLIP 640, CLIP 14014, CLIP 73019 (Centre de Référence des Listeria, Pasteur Institute, Paris, France) [19].

Plasmids pUC19 and Escherichia coli strain DH5 $\alpha$ were used for cloning experiments [20].

Unless otherwise stated, E. coli and Listeria spp. strains were grown overnight at $37^{\circ} \mathrm{C}$ (with shaking) in Luria Bertani (LB) medium and in Brain-Heart Infusion (BHI) broth (Difco Laboratories, Detroit, MI, USA), respectively. For E. coli containing pUC19, or derivatives, ampicillin was added to a final concentration of $100 \mu \mathrm{g} / \mathrm{ml}$.

\section{Preparation of bacterial extracts}

For preparation of E. coli sonicates, bacteria were grown overnight in $10 \mathrm{ml}$ of $\mathrm{LB}$ at $37^{\circ} \mathrm{C}$ (with shaking). The bacterial suspension was centrifuged at $10000 \mathrm{~g}$ for $10 \mathrm{~min}$ at $4^{\circ} \mathrm{C}$; cells were washed three times in phosphate-buffered saline, $\mathrm{pH} 7.2$ (PBS; $0.14 \mathrm{M} \mathrm{NaCl}, 2.7 \mathrm{mM} \mathrm{KCI}, 1.5 \mathrm{mM} \mathrm{KH}_{2} \mathrm{PO}_{4}, 8.1 \mathrm{mM}$ $\mathrm{Na}_{2} \mathrm{HPO}_{4} \cdot 2 \mathrm{H}_{2} \mathrm{O}$ ) and resuspended in $1 \mathrm{ml}$ of this buffer containing $10 \mathrm{mM}$ phenylmethysulphonyl fluoride (PMSF) and $1 \mathrm{~mm}$ EDTA. Cells were lysed by sonication (Sonics and Materials, Danbury, CT, USA) with ice-bath cooling. The protein concentration of the resulting sonicate was determined with Folin reagent (Sigma) with bovine serum albumin as the standard. Reagents were added to total sonicates to obtain the final concentration of a classic SDS-PAGE loading buffer (SDS $5 \% \mathrm{w} / \mathrm{v}, \quad \beta$-mercaptoethanol $10 \% \mathrm{v} / \mathrm{v}$, glycerol $20 \% \mathrm{v} / \mathrm{v}$, bromophenol blue $0.05 \% \mathrm{w} / \mathrm{v}$, $0.125 \mathrm{M}$ Tris-HCI, ( $\mathrm{pH} 6.8$ ) before storing at $-20^{\circ} \mathrm{C}$, until used.

\section{Separation of bacterial extracts (SDS-PAGE) and Western blot analysis}

Bacterial extracts were fractionated by SDS-PAGE (4 and $14 \%$ polyacrylamide for stacking and separating gels, respectively) under denaturing conditions. Electrophoresed components were then transferred from the polyacrylamide gel to polyvinylidene difluoride (PVDF) membranes by the use of a Transblot Unit (217 Multiphor 2, LKB, Bromma, Sweden). Transblotted membranes were incubated successively with a solution of human fibronectin (catalogue no. 688851; Boerhinger, Mannheim, Germany) $80 \mu \mathrm{g} / \mathrm{ml}$, with peroxidase-labelled rabbit anti-human fibronectin immunoglobulins (Dako, Copenhagen, Denmark) and were finally revealed by the addition of $\alpha$-chloronaphol and hydrogen peroxide, as described previously [14]. Reference samples of transblotted proteins and molecular mass markers were visualised by colloidal gold staining as indicated by the manufacturer (Aurodye forte, Amersham).

\section{Recombinant DNA techniques}

Unless otherwise stated all DNA cloning techniques were standard methods [21]. Plasmid DNA was purified with a Qiagen plasmid purification kit according to the manufacturer's protocol (Qiagen, Hilden, Germany). For preparation of L. monocytogenes DNA, bacteria from a 3-ml overnight culture were washed in $1 \mathrm{mM}$ EDTA, $0.1 \mathrm{M} \mathrm{NaCl}, 50 \mathrm{~mm}$ Tris-HCI ( $\mathrm{pH}$ 8.0) solution, suspended in $1 \mathrm{ml}$ of this solution containing lysozyme $2.5 \mathrm{mg}$ and incubated for $1 \mathrm{~h}$ at $37^{\circ} \mathrm{C}$. Then $25 \mu \mathrm{l}$ of a self-digested pronase $20 \mathrm{mg} / \mathrm{ml}$ solution and $50 \mu \mathrm{l}$ of an SDS $10 \%$ solution were added, followed by incubation for $2 \mathrm{~h}$ at $37^{\circ} \mathrm{C}$. The solution was extracted three times with an equal volume of a mixture of phenol-choloroform-isoamyl alcohol $(25: 24: 1)$ and traces of phenol 
were removed with ether. Five $\mu 1$ of a solution of boiled RNAase A $10 \mathrm{mg} / \mathrm{ml}, 15 \mathrm{mM} \mathrm{NaCl}, 10 \mathrm{mM}$ Tris-HCI ( $\mathrm{pH} 7.5)$ were added and incubation was continued for $1 \mathrm{~h}$ at $37^{\circ} \mathrm{C}$. The mixture was again extracted three times with the phenol-cholorform-isoamyl alcohol solution and then with ether. The DNA was precipitated with ethanol and suspended in $200 \mu \mathrm{l}$ of $0.1 \mathrm{mM}$ EDTA, $10 \mathrm{~mm}$ Tris-HCI (pH 7.4) buffer.

\section{DNA sequencing}

The sequence of the L. monocytogenes DNA cloned in pUC19-106 1 was determined by fluorescent dyeprimer cycle sequencing of both strands of the insert with Texas red-labelled primers, the Thermo Sequenase pre-mixed cycle sequencing kit from Amersham and the Vistra DNA Sequencer 725 apparatus (Amersham).

\section{PCR-restriction endonuclease analysis}

PCR amplifications from chromosomal DNA of Listeria spp. were performed with primers 5'CGGGATCCTGAAAGAGTTTATCGAGCCATACC-3' (Fig. 2, nucleotides 173-196) and 5'GGAATTCT TATTTACGTTTCTTAACAACCTC-3' (Fig. 2, nucleotides 819-796) and Taq DNA polymerase (Promega) according to the manufacturer's instructions. Amplifications were performed in a Perkin-Elmer thermocycler (Gene Amp ${ }^{\mathrm{R}}$ PCR system 24000) through the following temperature programme: one cycle of $45 \mathrm{~s}$ at $95^{\circ} \mathrm{C}$, then 35 cycles of $45 \mathrm{~s}$ at $95^{\circ} \mathrm{C}, 60 \mathrm{~s}$ at $55^{\circ} \mathrm{C}, 90 \mathrm{~s}$ at $72^{\circ} \mathrm{C}$ and finally one cycle of $10 \mathrm{~min}$ at $72^{\circ} \mathrm{C}$. After precipitation, $2 \mu \mathrm{g}$ of the amplified DNA fragment were digested with one of the following restriction endonucleases: Rsa I, Hha I, Dde I, Taq I, Mse I (Tru9I) or SacI, following the manufacturer's instructions (Promega). Restriction fragments were separated by agarose 2 or $4 \%$ gel electrophoresis, stained with ethidium bromide and visualised by transillumination under UV light.

\section{RNA isolation}

For extraction of total RNA from L. monocytogenes, the cells from $10 \mathrm{ml}$ of an overnight culture in BHI $\left(37^{\circ} \mathrm{C}\right)$ were harvested $\left(5000 \mathrm{~g}, 10 \mathrm{~min}, 4^{\circ} \mathrm{C}\right)$ and treated as described by Bashyam and Tyagi [22]. Purified RNA dissolved in $100 \mu \mathrm{l}$ DEPC-treated water was stored at $-70^{\circ} \mathrm{C}$ until used.

\section{RT-PCR}

For RT-PCR, $20 \mu \mathrm{g}$ of total RNA from L. monocytogenes were first incubated for $20 \mathrm{~min}$ at $25^{\circ} \mathrm{C}$ in a buffer containing amplification grade RNAase-free DNAase I (Gibco) $3 \mathrm{U}, 2 \mathrm{mM} \mathrm{MgCl}_{2}, 50 \mathrm{mM} \mathrm{KCl}$, $20 \mathrm{mM}$ Tris- $\mathrm{HCl}, \mathrm{pH}$ 8.4. DNAase I was inactivated by addition of EDTA (2.5 mM final concentration) and incubation at $65^{\circ} \mathrm{C}$ for $10 \mathrm{~min}$. Reverse transcription of mRNA encoding the $24.6-\mathrm{kDa}$ protein was performed for $45 \mathrm{~min}\left(37^{\circ} \mathrm{C}\right)$ in $50 \mu \mathrm{l}$ of a solution containing $4 \mu \mathrm{g}$ of DNA-free RNA, $10 \mathrm{pmol}$ primer 5'-GGAATTCTTATTTACGTTTCTTAACAACCTC-3' (Fig. 2, nucleotides 819-796), $1 \mathrm{mM}$ dNTP, $10 \mathrm{~mm}$ DTT, RNasin (Promega) $50 \mathrm{U}$, Moloney Murine Leukaemia Virus Reverse Transcriptase (Gibco) $200 \mathrm{U}, 3 \mathrm{mM} \mathrm{MgCl}_{2}, 75 \mathrm{mM} \mathrm{KCl}, 50 \mathrm{~mm}$ Tris- $\mathrm{HCl}$, $\mathrm{pH}$ 8.3. The reverse transcriptase was then inactivated (incubation for $10 \mathrm{~min}$ at $65^{\circ} \mathrm{C}$ ). Twenty $\mu \mathrm{l}$ of the reverse transcription reaction mixture were used for PCR amplification of the cDNA with the above primer plus primer 5'-CGGGATCCTGAAAGAGTTTATC GAGCCATACC-3' (Fig. 2, nucleotides 173-196), and Taq DNA polymerase, according to the manufacturer's instructions (Promega). Amplification was carried out in a Perkin-Elmer thermocycler (Gene Amp PCR system 24000) as described for the PCR-restriction analysis. Control RT-PCR reactions, omitting reverse transcriptase, were performed to check for DNA contamination of the RNA preparations.

\section{Nucleotide sequence accession number}

The sequence of the $f b p$ gene has been deposited in the EMBL database under accession number AJ132543.

\section{Results}

\section{Cloning of a fibronectin-binding protein gene}

To isolate gene(s) encoding L. monocytogenes protein(s) implicated in the binding of fibronectin, a DNA library was constructed in pUC19. Chromosomal DNA of strain 90/636 was partially digested with Sau3AI, ligated into the Bam HI site of plasmid pUC19 and used to transform E. coli DH5 $\alpha$. Pools of 10 E. coli recombinants were then grown overnight in the presence of IPTG. After sonication, E. coli proteins were separated by electrophoresis on an SDS-14\% polyacrylamide gel and transblotted to PVDF membranes, which were incubated with human fibronectin. Membranes were then compared for fibronectin binding to components not present in lysates of E. coli DH5a (pUC19), used as a control. A positive pool was found and screened for the clone expressing the listerial fibronectin-binding protein. Clone 106 was identified. This clone expresses a L. monocytogenes protein of $c$. $25 \mathrm{kDa}$, which avidly binds human fibronectin (Fig. 1B, lane 2). The binding is not non-specific binding to an overexpressed protein, as several proteins overexpressed by other clones failed to bind fibronectin (e.g., clone 128, Fig. 1B, lane 3).

Restriction endonuclease analysis of the pUC19-106 recombinant plasmid indicated that the listerial DNA insert is $2500 \mathrm{bp}$ long and contains two internal EcoRI sites (results not shown). As the length of the coding frame necessary to encode a $25-\mathrm{kDa}$ protein is $c$. $680 \mathrm{bp}$, it was decided to truncate the cloned fragment before sequencing. pUC19-106 was digested with 


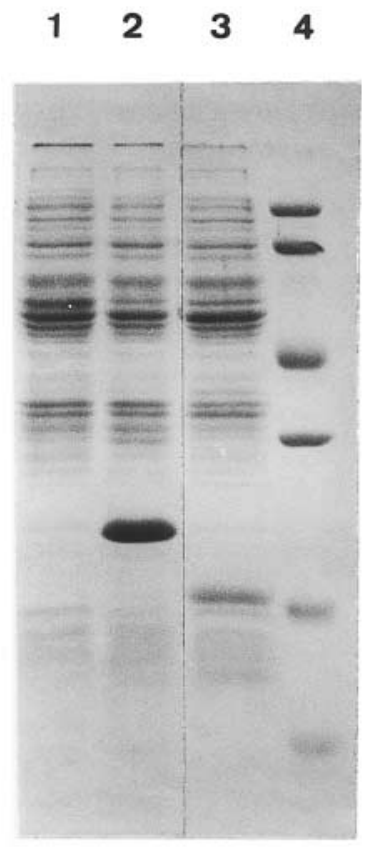

A

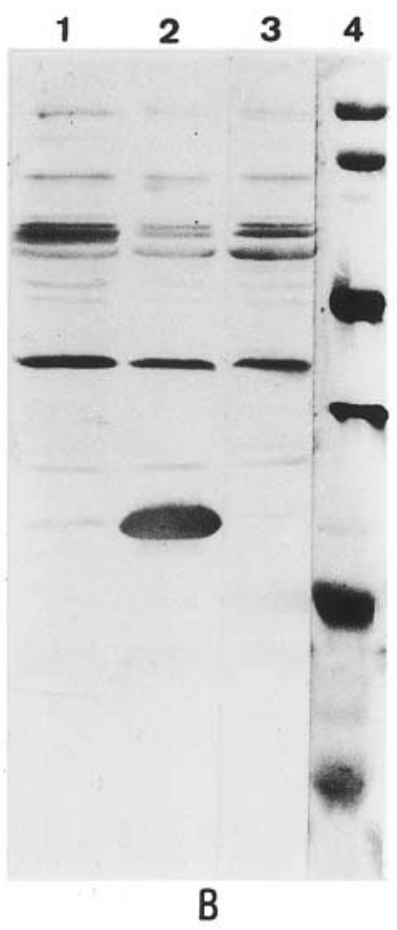

Fig. 1. Expression in E. coli of a L. monocytogenes fibronectin-binding protein. E. coli $\mathrm{DH} 5 \alpha$ clone 106 (lanes 2) and clone 128 (3), isolated from a genomic library of L. monocytogenes strain $90 / 636$ in pUC19 were grown overnight in the presence of ampicillin $100 \mu \mathrm{g} / \mathrm{ml}$ and $10 \mathrm{mM}$ IPTG. E. coli $\mathrm{DH} 5 \alpha$ transformed by pUC19 was treated in a similar manner and used as control (lanes 1). Total sonicates of the bacteria $(50 \mu \mathrm{g}$ of protein) were fractionated by SDS-14\% PAGE and either (A) stained with Coomassie Blue or (B) transferred to a PVDF membrane which was incubated with human fibronectin. Membrane-bound fibronectin was revealed by peroxidase-labelled rabbit anti-human fibronectin immunoglobulins and $\alpha$-chloronaphtnol as the substrate. Lanes 4, molecular mass markers $(94.0,67.0$, 43.0, 30.0, 20.1 and $14.2 \mathrm{kDa}$ from top to bottom, respectively) were stained with either (A) Coomassie Blue or (B) colloidal gold.

EcoRI, generating a 3650-bp DNA fragment (containing pUC19 and a 950-bp listerial DNA fragment), and a 900-bp listerial DNA fragment and a 600-bp listerial DNA fragment containing part of the pUC19 multiple cloning site (from the Bam HI to the EcoRI sites). The 3650-bp fragment was self-ligated and used to transform $E$. coli $\mathrm{DH} 5 \alpha$, generating clone $106 \Delta 1$. Clone $106 \Delta 1$ was shown to overexpress a $25-\mathrm{kDa} L$. monocytogenes protein which binds human fibronectin (results not shown).

Expression of the $25-\mathrm{kDa}$ protein was not influenced by IPTG (data not shown) in either clone 106 or $106 \Delta 1$, suggesting that the $25-\mathrm{kDa}$ protein gene is transcribed in E. coli from its own promoter.

\section{Sequencing of the gene ( $f b p$ ) encoding the $L$. monocytogenes 25-kDa protein}

The sequence of the L. monocytogenes DNA fragment inserted in clone $106 \Delta 1$ was determined on both strands (Fig. 2). The 951-bp listerial DNA insert has a $\mathrm{G}+\mathrm{C}$ content of $37.6 \mathrm{~mol} \%$, which is in the $37-$ $39 \mathrm{~mol} \%$ range of the $\mathrm{G}+\mathrm{C}$ content of all $L$. monocytogenes chromosomal DNA [23]. The presence of four stop codons, in frame with the pUC19 $\alpha$ peptide, in the first 160 nucleotides of the sequence excludes the expression of an $\alpha$-peptide-fibronectinbinding fusion protein in $E$. coli. The cloned DNA contains only one large open reading frame extending from position 172 to 819 . This 648-bp open reading frame (ORF) encodes a polypeptide of 215 amino acids (calculated mol. wt of $24.6 \mathrm{kDa}$ ). The initiation codon of the 648-bp ORF is an ATG and is preceded by the sequence TAAAGGAGA (nucleotides 157-165) which is complementary to the $3^{\prime}$ end of the 16S rRNA of both L. monocytogenes and E. coli [24-26]. Therefore, this sequence, located six bases upstream of the start codon, may represent a ribosome-binding site for the mRNA encoded by the $f b p$ gene in both $E$. coli and $L$. monocytogenes. The ORF is terminated by a TAA stop codon, followed immediately by a 26-bp inverted repeat (with only two mismatches) which could form a secondary structure with a free energy $\left(\Delta \mathrm{G}\right.$ at $\left.25^{\circ} \mathrm{C}\right)$ of $-26.0 \mathrm{kcal} / \mathrm{mol}$ [27], and therefore function as a rho-independent transcription terminator. A palindromic sequence (convergent dotted arrows in Fig. 2) with homology to the 14-bp canonical binding box of PrfA, a regulator of the expression of several listerial virulence genes [28-38, EMBL X97014], was detected $20 \mathrm{bp}$ upstream of the initiation codon ATG. This PrfAlike box (boxed in Fig. 2) has three mismatches compared to the perfect palindrome (TTAACANNTGT TAA). Despite the presence of this 'PrfA-like' box, RNA transcripts of the $f b p$ gene were found in wildtype L. monocytogenes strains (90/636 and LO28), in a $\triangle p r f A$ strain (BUG 802) and in a strain (BUG 1236) overexpressing a mutated PrfA protein possessing a higher affinity for PrfA boxes than its wild-type analogue (PrfA-S183A) (Fig. 3).

The predicted 215 amino-acids sequence has a calculated iso-electric point of 7.63 and is rich in lysine $(11.2 \%)$ residues, distributed throughout the molecule. Apart from these characteristics, other notable features are a repeated amino-acid block (EFIE) at the ends of the protein (positions 3-6 and 206-209) and another (AKTK) in the middle of the protein (positions 99-102 and 170-173). A cytochrome $\mathrm{C}$ family haem-binding signature (Prosite PDOC00169) was also present at positions 156-161. Protein and nucleotide database searches (BLAST P and BLAST N programs) found no significant similarity with any other known protein or nucleic acid sequences.

\section{Detection of sequences homologous to the $\mathrm{fbp}$ gene among Listeria species}

To study the occurrence of the $f b p$ gene in strains of L. monocytogenes, PCR-amplification of the complete 
Sau $3 A$

1 gatctcgttccaatagccgagagccgtcgtgatcaagagatgcaacaaattgcactgctctcgactttctaacaatg

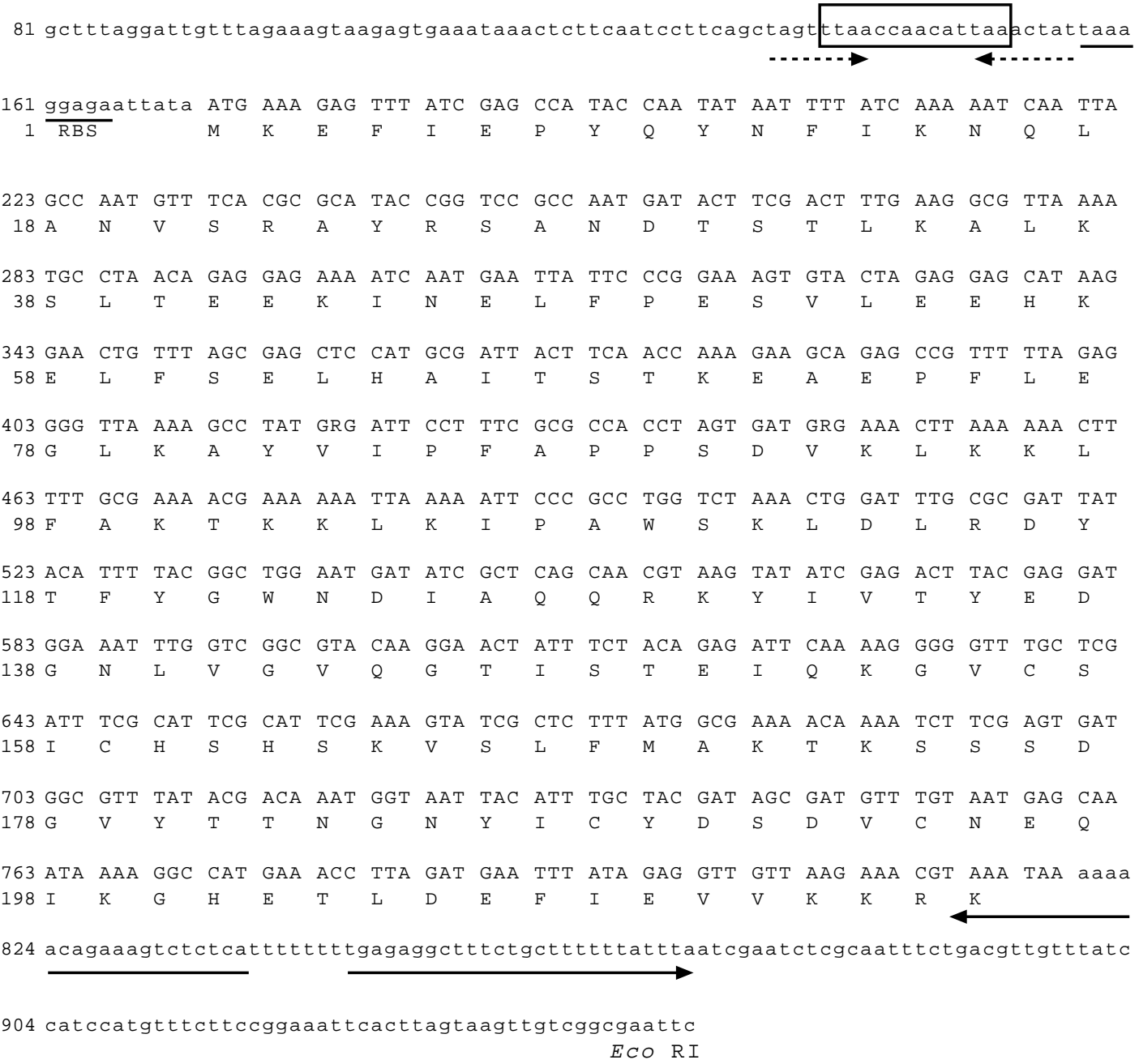

Fig. 2. Nucleotide sequence of the region containing the gene encoding the Fbp of L. monocytogenes. The sequence of the gene and of its translation product (single-letter amino-acid code) are shown. The potential ribosome binding site (RBS) is underlined. A palindromic sequence (dotted convergent arrows) extending from a boxed PrfA-like binding site is indicated. Large divergent arrows at the end of the ORF indicate a predicted rho-independent transcription terminator.

$648 \mathrm{bp}$ ORF was performed with chromosomal DNA purified from 20 strains of non-clonal origin. Each of these strains belongs to one of the 20 different esterase types detected during a previously made analysis of $L$. monocytogenes populations isolated from foodstuffs and from human patients with listeriosis in Belgium (see Materials and methods) [15,39]. In all the tested strains, a 648-bp DNA fragment was amplified, indicating a broad distribution of the $f b p$ gene in this species (results not shown). The occurrence of the $f b p$ gene in other species of the genus Listeria was also tested by PCR. No DNA amplification was observed with chromosomal DNA purified from three strains of $L$. grayi, three strains of $L$. seeligeri, three strains of $L$. innocua or one strain of $L$ ivanovii; but a DNA fragment of similar size was amplified from the chromosomal DNA of 15 strains of L. welshimeri (Fig. 4 and results not shown).
The PCR-amplified $f b p$ gene of L. monocytogenes strain 90/636 used as a probe was then hybridised under high stringency to Sca I-digested DNA from several strains of the five different Listeria species. This probe hybridised to a $c$. 7500-bp fragment of DNA from L. monocytogenes, but not to DNA from the other Listeria species analysed, including L. welshimeri (results not shown).

The above results suggest that only some regions of the 648-bp DNA fragment amplified in L. welshimeri and in L. monocytogenes are homologous. This hypothesis was tested by restriction endonuclease analysis of the molecules amplified from the DNA of the $20 \mathrm{~L}$. monocytogenes strains and the $15 \mathrm{~L}$. welshimeri strains described above. Six restriction endonucleases (RsaI, SacI, Hha I, Mse I, Dde I and Taq I) cutting at sites covering the entire Fbp ORF of 


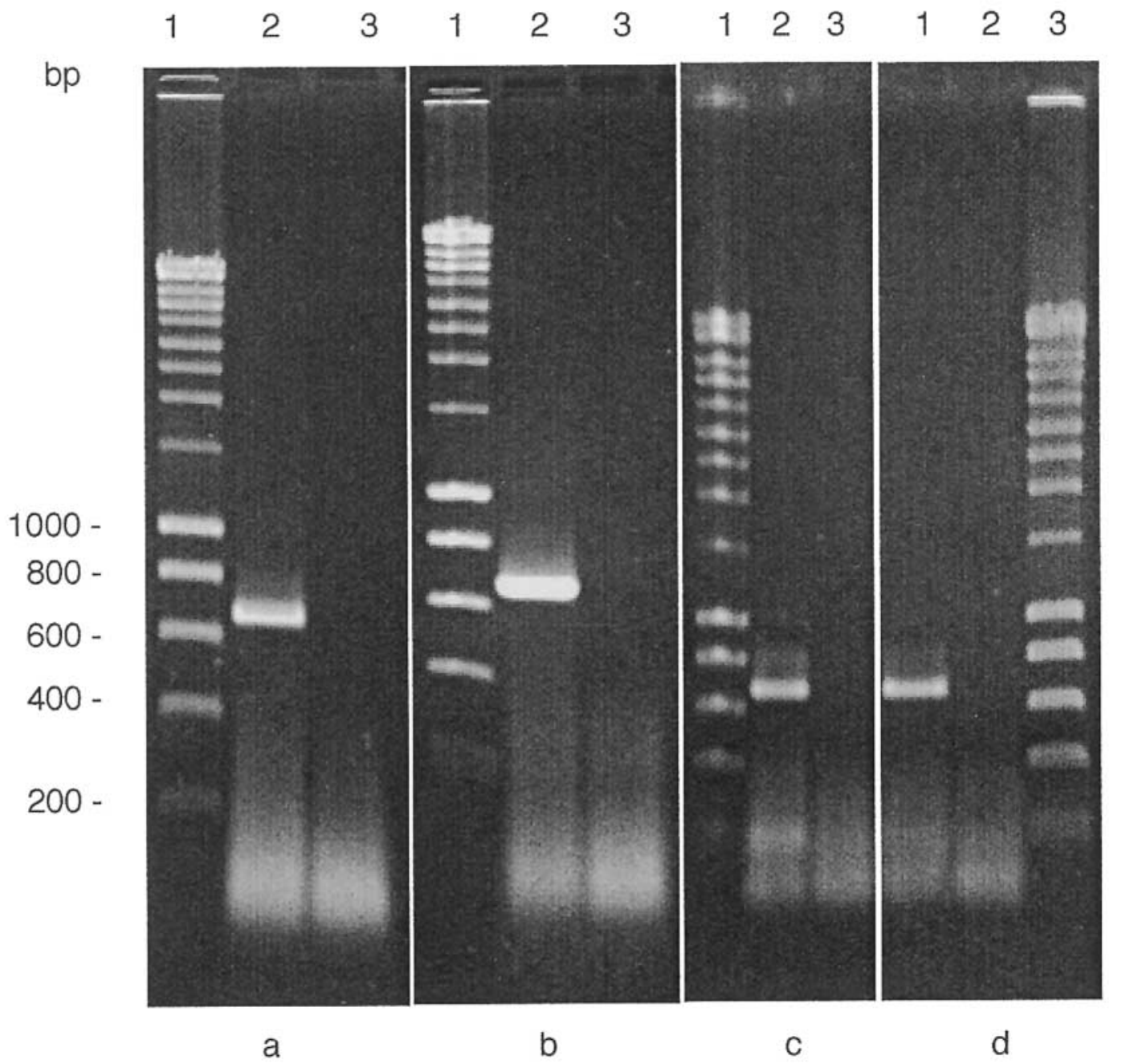

Fig. 3. Transcription of the $f b p$ gene in wild-type, $\Delta p r f \mathrm{~A}$ and PrfA-S183A strains of L. monocytogenes. L. monocytogenes wild-type strain 90/636 (a), wild-type strain LO28 (c), strain LO28 $\Delta$ prfA (BUG 802) (b) and strain LO28 PrfA-S183A (BUG 1236) (d) total RNA were extracted. Reverse transcriptions of mRNA encoding the FBP protein were performed and the cDNAs obtained were used for PCR amplifications (lanes a2, b2, c2 and d1). Control RT-PCR reactions made in the absence of reverse transcriptase were performed to check for DNA contamination (lanes a3, b3, c3 and d2). Mol. wt markers (Smart DNA ladder, Eurogentec) of the indicated size are in lanes a1, b1, c1 and d3.

L. monocytogenes strain 90/636 were chosen (Fig. 5b). These experiments confirmed the nucleotide sequences of the $f b p$ gene of strain $90 / 636$ and showed that this gene displays a low degree of allelic variation among isolates: all the strains hydrolysed with $M s e I$ and with Hha I have the same restriction profiles (Fig. 5a; lanes 1 and 12, respectively), and only two different profiles were observed with each of the four other enzymes tested (Fig. 5a; lanes 4 and 5 for RsaI, lanes 8 and 9 for Sac I, lanes 15 and 16 for DdeI, and lanes 19 and 20 for TaqI). In contrast, the DNA fragments amplified from the L. welshimeri strains are completely monomorphic (Fig. 5a; lanes 2, 6, 10, 13, 17 and 21). Interestingly, the enzymes HhaI, Dde I and Taq I produced banding profiles of the $L$. welshimeri amplified DNA fragment different from those observed for the L. monocytogenes Fbp ORF, allowing a specific identification of each species (Fig. 5a).

\section{Discussion}

In this study the gene for a $24.6-\mathrm{kDa}$ protein of $L$. monocytogenes that binds human fibronectin was cloned and sequenced. No homology was found between the listerial Fbp and known fibronectin-binding domains of other prokaryotic or eukaryotic proteins, including the RGD motif of integrins. The biological relevance and putative role of the Fbp during listerial infection is thus speculative. Nevertheless, it is worth noting that, whereas some homologies have been found between streptococcal and staphylococcal fibronectin-binding domains, these binding sites are completely different from those of mycobaterial fibronectin-binding protein [40-46]. This indicates that pathogens have evolved several different mechanisms for binding to fibronectin and that the one used by L. monocytogenes could be original to this species. 


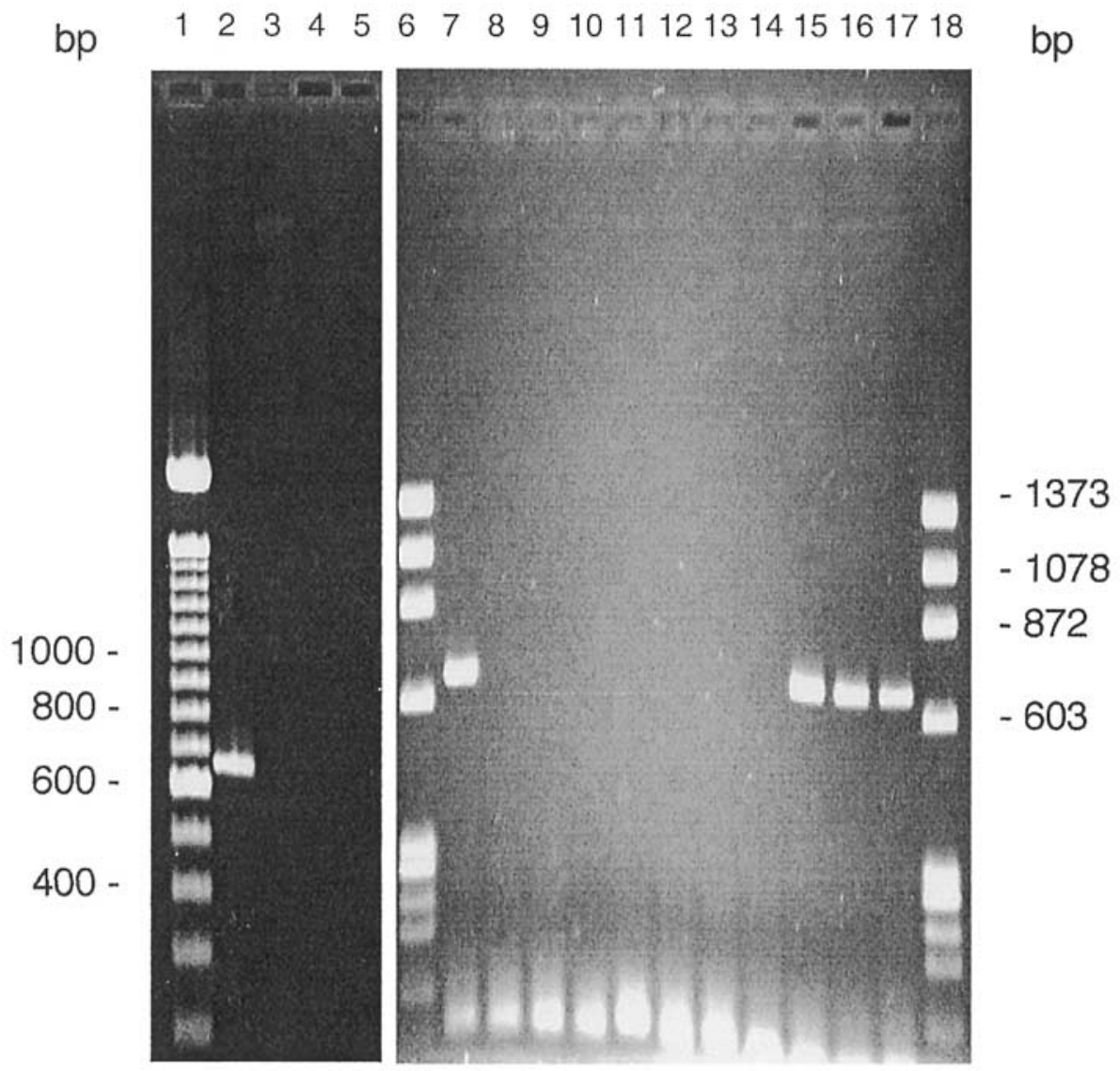

Fig. 4. Search for DNA sequences homologous to the $f b p$ gene of $L$. monocytogenes. Chromosomal DNAs of $L$. monocytogenes 90/636 (lanes 2, 7), L. grayi CLIP 73019 (3), L. grayi CLIP 640 (4), L. grayi CLIP 14014 (5), L. innocua sv 6a (8), L. innocua sv 6b (9), L. innocua 95/013 (10), L. seeligeri 024/20 (11), L. seeligeri 89/59/06 (12), L. seeligeri 1140/09/03 (13), L. ivanovii (14), L. welshimeri P.P. (15), L. welshimeri 90/060/01 (16) and L. welshimeri 90/060/02 (17) were purified. The DNAs were used for the PCR-amplification of the Fbp ORF. Amplification products were separated on an agarose $1.5 \%$ gel and visualised under UV light. Mol. wt markers of the indicated size are in lanes 1 (100-bp DNA ladder) and 18 ( $\phi$ X174 DNA cut by Hae III).

The presence of a putative prfA box upstream of the Shine-Dalgarno sequence of the $f b p$ gene is puzzling, as such a palindromic sequence at this position would represent an ideal repressor site. PrfA is mainly known as an activator of several virulence Listeria genes. PrfA-controlled genes are preceded by conserved 14-bp long DNA sequences (PrfA boxes), centred near position -40 [28-38, EMBL X97014]. PrfA-dependent genes are differently regulated: promoters with perfect palindromes are transcribed more efficiently than those having mismatches and a 'PrfA-site hierarchy' model was proposed to explain these findings. Recently 'pseudo PrfA boxes' also located between the transcriptional start site and the translational start triplet were described. These boxes resemble a conventional PrfA box, but have larger loop structures. These PrfA boxes were also claimed to be important for the expression of their downstream genes $[32,36]$. The complexity of regulation by PrfA has been reinforced by observations made on motility genes and on the stress response mediator $\mathrm{ClpC}$, indicating that PrfA is responsible for downregulation of these genes by an as yet unknown mechanism $[47,48]$. Despite the presence of a putative PrfA box near the RBS on the $f b p$ gene,
RNA transcripts of this gene were found in wild-type strains, in a strain deleted of prfA and in a strain overexpressing a PrfA protein with a high affinity for PrfA boxes. This indicates that the identified 'PrfAlike' box is not implicated in an absolute 'switch onswitch off' mechanism of regulation of the $f b p$ gene transcription. However, as far as the RT-PCR used could be considered as being quantitative, it seems that PrfA could somewhat downregulate the transcription of the $f p b$ gene as more transcripts were revealed in the $\triangle$ prfA strain (Fig. 3). Other explanations for the putative role of this palindromic box would be its use as a PrfA binding site for the regulation of a gene transcribed in the direction opposite to the $f b p$ gene or as a binding site of another not yet identified regulator.

The PCR based on the $f b p$ gene was found to be specific for L. monocytogenes and L. welshimeri strains (Fig. 4). As parts of the amplified sequences are dissimilar in these two species, digestion of the amplified products with the enzymes $H h a \mathrm{I}, D d e \mathrm{I}$ or Taq I were able to produce specific banding patterns for L. monocytogenes and for L. welshimeri strains (Fig. 

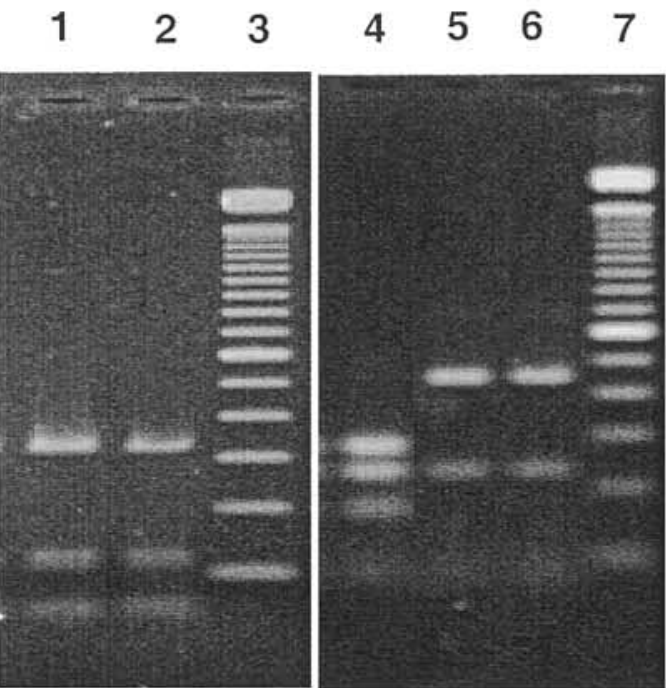

Mse I

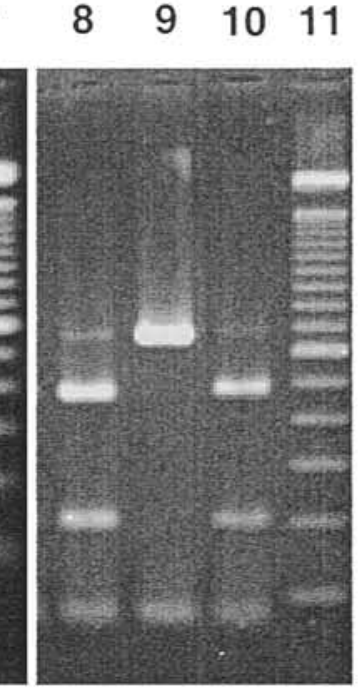

Sac I
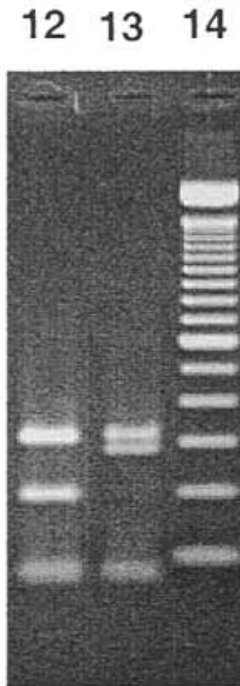

1516

$17 \quad 18$

$\begin{array}{lllll}8 & 19 & 20 & 21 & 22\end{array}$

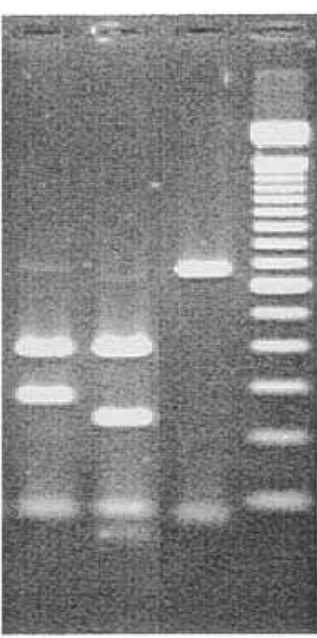

Hha I

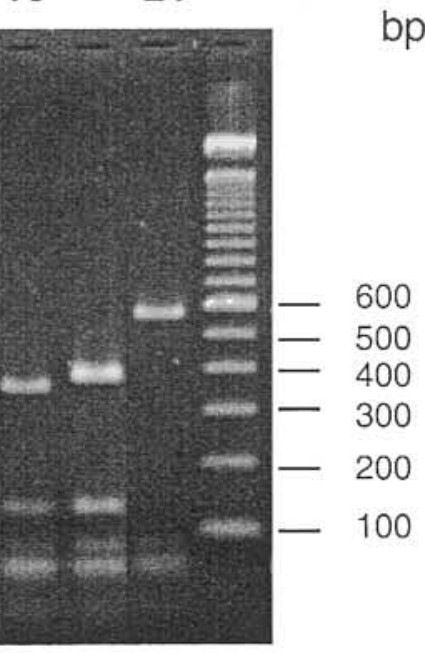

Taq I

b

317 Msel.

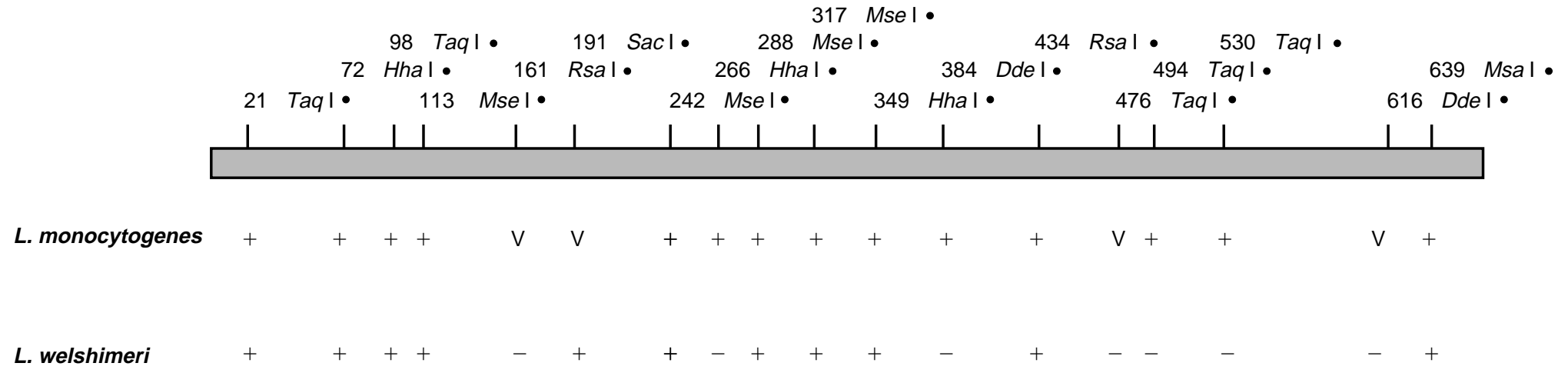

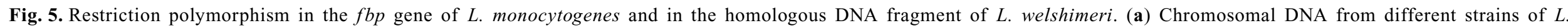

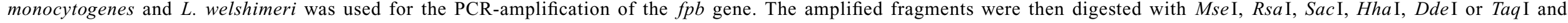

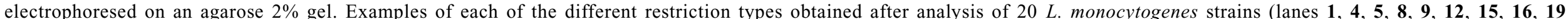

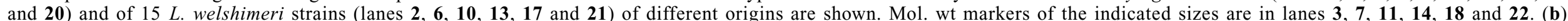

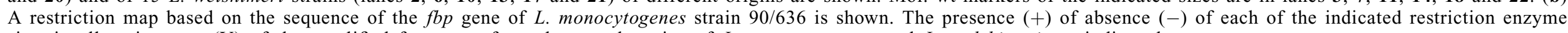
sites in all or in some (V) of the amplified fragments from the tested strains of L. monocytogenes and L. welshimeri are indicated. 
5). Therefore this RE-PCR technique could be used as a new tool for identification of $L$. monocytogenes and L. welshimeri among species of the genus Listeria.

We are grateful to P. Cossart (Pasteur Institute, Paris, France), A. Genicot (Institute of Hygiene and Epidemiology, Brussels, Belgium), C. Jacquet (Pasteur Institute, Paris) and J. Rocourt (Pasteur Institute, Paris) for providing strains of Listeria spp., and to M. Braibant for critical reading of the manuscript. This work was part of an application that received the award of the Eugene Yourassowski Foundation (Brussels).

\section{References}

1. Dalton CB, Austin CC, Sobel J et al. An outbreak of gastroenteritis and fever due to Listeria monocytogenes in milk. N Engl J Med 1997; 336: 100-105.

2. Farber JM, Peterkin PI. Listeria monocytogenes, a food-borne pathogen. Microbiol Rev 1991; 55: 476-511.

3. Bille J, Rocourt J, Swaminathan B. Listeria, Erysipelothrix and Kurthia. In: Murray PR, Baron EJ, Pfaller M, Tenover F, Yolke $\mathrm{R}$ (eds) Manual of clinical microbiology. Washington, DC, ASM Press. 1999: 346-356.

4. McLauchlin J. The pathogenicity of Listeria monocytogenes: a public health perspective. Rev Med Microbiol 1997; 8: 1-14.

5. Gilot P, Hermans C, Yde M et al. Sporadic case of listeriosis associated with the consumption of a Listeria monocytogenescontaminated 'Camembert' cheese. J Infect 1997; 35: 195-197.

6. Pandiripally VK, Westbrook DG, Sunki GR, Bhunai AK. Surface protein p104 is involved in adhesion of Listeria monocytogenes to human intestinal cell line, Caco-2. J Med Microbiol 1999; 48: 117-124.

7. Braun L, Ohayon H, Cossart P. The InIB protein of Listeria monocytogenes is sufficient to promote entry into mammalian cells. Mol Microbiol 1998; 27: 1077-1087.

8. Mengaud J, Ohayon H, Gounon P, Mège R, Cossart P. Ecadherin is the receptor for internalin, a surface protein required for entry of $L$. monocytogenes into epithelial cells. Cell 1996; 84: 923-932.

9. Kuhn M, Goebel W. Identification of an extracellular protein of Listeria monocytogenes possibly involved in intracellular uptake by mammalian cells. Infect Immun 1989; 57: 55-61.

10. Alvarez-Domínguez C, Vázquez-Boland J-A, Carrasco-Marín E, López-Mato P, Levya-Cobián F. Host cell heparan sulfate proteoglycans mediate attachment and entry of Listeria monocytogenes, and the listerial surface protein ActA is involved in heparan sulfate receptor recognition. Infect Immun 1997; 65: 78-88.

11. Cowart RE, Lashmet J, McIntosh ME, Adams TJ. Adherence of a virulent strain of Listeria monocytogenes to the surface of a hepatocarcinoma cell line via lectin-substrate interaction. Arch Microbiol 1990; 153: 282-286.

12. Maganti S, Pierce MM, Hoffmaster A, Rodgers FG. The role of sialic acid in opsonin-dependent and opsonin-independent adhesion of Listeria monocytogenes to murine peritoneal macrophages. Infect Immun 1998; 66: 620-625.

13. Dunne DW, Resnick D, Greenberg J, Krieger M, Joiner KA. The type I macrophage scavenger receptor binds to grampositive bacteria and recognizes lipoteichoic acid. Proc Natl Acad Sci USA 1994; 91: 1863-1867.

14. Gilot P, André P Content J. Listeria monocytogenes possesses adhesins for fibronectin. Infect Immun 1999; 67: 6698-6701.

15. Gilot P, Genicot A, André P. Serotyping and esterase typing for analysis of Listeria monocytogenes populations recovered from foodstuffs and from human patients with listeriosis in Belgium. $J$ Clin Microbiol 1996; 34: 1007-1010.

16. Vicente MF, Baquero F, Pérez-Diaz JC. Cloning and expression of the Listeria monocytogenes haemolysin in Escherichia coli. FEMS Microbiol Lett 1985; 30: 77-79.

17. Sheehan B, Karlsfeld A, Msadek T, Cossart P. Differential activation of virulence gene expressison by PrfA, the Listeria monocytogenes virulence regulator. J Bacteriol 1995; 177: 6469-6476.

18. Sheehan B, Klarsfeld A, Ebright R, Cossart P. A single substitution in the putative helix-turn-helix motif of the pleiotropic activator PrfA attenuates Listeria monocytogenes virulence. Mol Microbiol 1996; 20: 785-797.
19. Rocourt J, Boerlin P, Grimont F, Jacquet C, Piffaretti J-C. Assignment of Listeria grayi and Listeria murrayi to a single species, Listeria grayi, with a revised description of Listeria grayi. Int J Syst Bacteriol 1992; 42: 181-174.

20. Yanisch-Perron C, Vieira J, Messing J. Improved M13 phage cloning vectors and host strains: nucleotide sequences of the M13mp18 and pUC19 vectors. Gene 1985; 33: 103-119.

21. Sambrook J, Fritsch EF, Maniatis T. Molecular cloning. A laboratory manual, 2nd edn. Cold Spring Harbor, NY, Cold Spring Harbor Laboratory Press. 1989.

22. Bashyam M, Tyagi A. An efficient and high-yielding method for isolation of RNA from mycobacteria. Biotechniques 1994; 17: $834-836$.

23. Seeliger HPR, Jones D. Listeria. In: Sneath PH, Mair NS, Sharpe ME, Holt JG (eds) Bergey's manual of systematic bacteriology, vol. 2. Baltimore, Williams \& Wilkins. 1986: $1235-1245$.

24. Collins MD, Wallbanks S, Lane DJ et al. Phylogenetic analysis of the genus Listeria based on reverse transcriptase sequencing of 16S rRNA. Int J Syst Bacteriol 1991; 41: 240-246.

25. Czajka J, Bsat N, Piani $M$ et al. Differentiation of Listeria monocytogenes and Listeria monocytogenes strains by random amplified polymorphic DNA polymorphisms. Appl Environ Microbiol 1993; 59: 304-308.

26. Gutell RR, Larsen N, Woese CR. Lessons from an evolving rRNA: $16 \mathrm{~S}$ and 23S rRNA structures from a comparative perspective. Microbiol Rev 1994; 58: 10-26.

27. Tinoco I, Borer PN, Dengler B et al. Improved estimation of secondary structure in ribonucleic acids. Nat New Biol 1973; 246: $40-41$.

28. Mengaud J, Vicente MF, Cossart P. Transcriptional mapping and nucleotide sequence of the Listeria monocytogenes hylA region reveal structural features that may be involved in regulation. Infect Immun 1989; 57: 3695-3701.

29. Vazquez-Boland J-A, Kocks C, Dramsi S et al. Nucleotide sequence of the lecithinase operon of Listeria monocytogenes and possible role of lecithinase in cell-to-cell spread. Infect Immun 1992; 60: 219-230.

30. Freitag NE, Rong L, Portnoy DA. Regulation of the prfA transcriptional activator of Listeria monocytogenes: multiple promoter elements contribute to intracellular growth and cellto-cell spread. Infect Immun 1993; 61: 2537-2544.

31. Dramsi S, Kocks C, Forestier C, Cossart P. Internalin-mediated invasion of epithelial cells by Listeria monocytogenes is regulated by the bacterial growth state, temperature and pleitropic activator prfA. Mol Microbiol 1993; 9: 931-941.

32. Engelbrecht F, Chun S-K, Ochs C et al. A new PrfA-regulated gene of Listeria monocytogenes encoding a small, secreted protein which belongs to the family of internalins. Mol Microbiol 1996; 21: 823-837.

33. Dramsi S, Dehoux P, Lebrun M, Goossens PL, Cossart P. Identification of four new members of the internalin multigene family of Listeria monocytogenes EGD. Infect Immun 1997; 65: $1615-1625$

34. Lampidis R, Gross R, Sokolovic Z, Goebel W, Kreft J. The virulence regulator protein of Listeria ivanovii is highly homologous to PrfA from Listeria monocytogenes and both belong to the Crp-Fnr family of transcription regulators. Mol Microbiol 1994; 13: 141-151.

35. Kreft J. Corrigendum to 'The actin-polymerization protein from Listeria ivanovii is a large repeat protein which shows only limited amino acid sequence homology to ActA from Listeria monocytogenes.' FEMS Microbiol Lett 1995; 132: $181-182$.

36. Engelbrecht F, Dickneite C, Lampidis R, Gotz M, DasGupta U, Goebel W. Sequence comparison of the chromosomal regions encompassing the internalin $\mathrm{C}$ genes (inlC) of Listeria monocytogenes and L. ivanovii. Mol Gen Genet 1998; 257: 186-197.

37. Engelbrecht F, Dominguez-Bernal G, Hess J et al. A novel PrfA-regulated chromosomal locus, which is specific for Listeria ivanovii, encodes two small, secreted internalins and contributes to virulence in mice. Mol Microbiol 1998; 30: 405-417.

38. Karunasagar I, Lampidis R, Goebel W, Kreft J. Complementation of Listeria seeligeri with the plcA-prfA genes from $L$ monocytogenes activates transcription of seeligerolysin and leads to bacterial escape from the phagosome of infected mammalian cells. FEMS Microbiol Lett 1997; 146: 303-310. 
39. Gilot P, André P. Characterization of five esterases from Listeria monocytogenes and use of their electrophoretic polymorphism for strain typing. Appl Environ Microbiol 1995; 61: 1661-1665.

40. Foster TJ, Höök M. Surface protein adhesins of Staphylococcus aureus. Trends Microbiol 1998; 6: 484-488.

41. Jaffe J, Natanson-Yaron S, Caparon MG, Hanski E. Protein F2, a novel fibronectin-binding protein from Streptococcus pyogenes, possesses two binding domains. Mol Microbiol 1996; 21: $373-384$

42. Joh HJ, House-Pompeo K, Patti JM, Gurusiddappa S, Höök M. Fibronectin receptors from gram-positive bacteria: comparison of active sites. Biochemistry 1994; 33: 6086-6092.

43. Naito $M$, Ohara $N$, Matsumoto $S$, Yamada T. The novel fibronectin-binding motif and key residues of mycobacteria. $J$ Biol Chem 1998; 273: 2905-2909.

44. Ozeri V, Tovi A, Burstein I et al. A two-domain mechanism for group A streptococcal adherence through protein $\mathrm{F}$ to the extracellular matrix. EMBO J 1996; 15: 989-998.

45. Schorey JS, Holsti MA, Ratliff TL, Allen PM, Brown EJ. Characterization of the fibronectin-attachment protein of Mycobacterium avium reveals a fibronectin-binding motif conserved among mycobacteria. Mol Microbiol 1996; 21: 321-329.

46. Westerlund B, Korhonen TK. Bacterial proteins binding to the mammalian extracellular matrix. Mol Microbiol 1993; 9: 687694.

47. Michel E, Mengaud J, Galsworthy S, Cossart P. Characterization of a large motility gene cluster containing the cheR, motAB genes of Listeria monocytogenes and evidence that PrfA downregulates motility genes. FEMS Microbiol Lett 1998; 169: 341-347.

48. Ripio M-T, Vazques-Boland J-A, Vega Y, Nair S, Berche P. Evidence for expressional crosstalk between the central virulence regulator PrfA and the stress response mediator ClpC in Listeria monocytogenes. FEMS Microbiol Lett 1998; 158: 45-50. 